CARDOSO, FR; BRASILEIRO, LO; RAGASSI, CF; CARVALHO, ADF; SILVA, PP; VIEIRA, JV; NASCIMENTO, WM. 2021. Morpho-agronomic characterization and genetic divergence in lentil genotypes. Horticultura Brasileira 39: 169-177. DOI: http://dx.doi.org/10.1590/s0102-0536-20210207

\title{
Morpho-agronomic characterization and genetic divergence in lentil genotypes
}

\author{
Fabiana R Cardoso ${ }^{1} \mathbb{D}$; Lemerson de O Brasileiro ${ }^{1} \mathbb{D}$; Carlos Francisco Ragassi ${ }^{2} \mathbb{D}$; Agnaldo DF de \\ Carvalho $^{2 \mathbb{D}}$; Patrícia P da Silva ${ }^{2} \mathbb{D}$; Jairo V Vieira ${ }^{2} \mathbb{D}$; Warley Marcos Nascimento ${ }^{1,2 \mathbb{D}}$
}

${ }^{1}$ Universidade de Brasília (UnB), Faculdade de Agronomia e Medicina Veterinária, Brasília-DF, Brasil; fabianarcardoso@yahoo.com.br; lemerson.oli@gmail.com; ${ }^{2} E m b r a p a$ Hortaliças, Brasília-DF, Brasil; cragassi@gmail.com; agnaldo.carvalho@embrapa.br; patricia.pereira@ colaborador.embrapa.br; jairovvieira@gmail.com; warley.nascimento@embrapa.br

\begin{abstract}
Lentil production has been increasing in Brazil, due to strong national and international demand. Despite the economic importance, few cultivars are available on the Brazilian market. The aim of this study was to evaluate 48 lentil inbred lines and one commercial cultivar (Silvina), based on morpho-agronomic traits and to identify genotypes which can be used in a plant breeding program. Twentyone morpho-agronomic descriptors (nine qualitative and twelve quantitative) were used. The descriptors showed genetic variability among the genotypes. Clustering techniques using characterization data allowed to identify genetically divergent genotypes as well as identify superior genotypes in relation to agronomic traits: FLIP2010-8L and FLIP2010-12L (similarity group I), FLIP201099L, FLIP2010-20L and FLIP2010-106L (group II), FLIP90-25L and 6031 (group III), FLIP2007-16L (group IV) and the commercial cultivar Silvina (group V). We concluded that these genotypes have the potential to be used in lentil breeding programs.
\end{abstract}

Keywords: Lens culinaris, genetic resources, genetic variability, productivity.

\section{RESUMO}

Caracterização morfoagronômica e divergência genética em genótipos de lentilha

A produção de lentilha apresenta tendência de crescimento no Brasil devido a uma forte demanda do mercado nacional e internacional por esta hortaliça leguminosa. Apesar da importância econômica, existem poucas cultivares disponíveis no mercado brasileiro. $\mathrm{O}$ objetivo deste estudo foi avaliar 48 linhagens de lentilha e uma cultivar comercial (Silvina), com base em características morfoagronômicas, e identificar genótipos que possam ser empregados no melhoramento genético. Foram utilizados 21 descritores morfoagronômicos (nove qualitativos e doze quantitativos) que evidenciaram a existência de variabilidade genética entre os genótipos estudados. A associação das técnicas de agrupamento com os dados de caracterização possibilitou a identificação de genótipos geneticamente divergentes e, ao mesmo tempo, superiores quanto a características agronômicas: FLIP2010-8L e FLIP2010-12L (grupo de similaridade I), FLIP201099L, FLIP2010-20L e FLIP2010-106L (grupo II), FLIP90-25L e 6031 (grupo III), FLIP2007-16L (grupo IV) e a cultivar comercial Silvina (grupo V). Esses genótipos apresentam potencial para serem utilizados em programas de melhoramento genético da espécie.

Palavras-chave: Lens culinaris, recursos genéticos, variabilidade genética, produtividade.

\section{Received on July 15, 2020; accepted on April 5, 2021}

L entil (Lens culinaris) belongs to Fabaceae family. This crop is of great importance for global economy, and it stands out for its nutritional value and food safety issues for millions of people around the world, especially in underdeveloped countries (Rawal \& Bansal, 2019). The grains are nutritive, rich in proteins, carbohydrates, micronutrients, vitamins and aminoacids, lysine and tryptophan (Shahwar et al., 2017). The commercial use of lentils includes whole grain, split, peeled or processed as flour. The plant can fix atmospheric nitrogen in association with Rhizobium sp. (Rasheed et al., 2020), and the cultivation is a good possibility for crop rotation or succession, since lentil benefits, directly, soil fertility (Liu et al., 2019). Besides, the plant shows climatic adaptability (Strydhorst et al., 2015), which makes it widely distributed around the world.

Nowadays, Canada is the largest producer and exporter of lentil, $32.8 \%$ of total global production. Although India is the country with the largest cultivated area, about $25.4 \%$ of world production (Faostat, 2020), the country has low average crop productivity $\left(731 \mathrm{~kg} \mathrm{ha}^{-1}\right)$ comparing with the average productivity worldwide $\left(1.041 \mathrm{~kg} \mathrm{ha}^{-1}\right)$ (Faostat, 2020). This low productivity leads the Indian country to frequent imports of green and red lentils in order to meet its own demand. Brazilian lentil production is still negligible and domestic demand is supplied by imports, mainly from Canada, Argentina and The United States. In 2020, Brazil imported about 21 thousand tons, which means about US\$ 13.3 millions on lentil import (Comex Stat, 2021).

In Brazil, mainly in Midwest region, lentil is an excellent option 
for drip-irrigated crop during winter, reaching average productivities of 1.200 to $1.600 \mathrm{~kg} \mathrm{ha}^{-1}$ in experimental conditions (Giordano \& Nascimento, 2009). Sowing can be performed in April or May, and optimal temperatures for germination and development of the crop are 18 and $24^{\circ} \mathrm{C}$, respectively (Vieira \& Lima, 2016). Thus, due to the productive potential verified, favorable climatic conditions and to an increasing demand of national and international market, mainly the Indian markets, Brazilian agribusiness is able to consolidate its production.

Although few lentil breeding studies have been carried out in Brazil in 1999, cultivar Silvina was released (Embrapa Hortaliças, 2014) for green lentil production, big seed (type macrosperm) and yellow cotyledon, the preferred type among Brazilian consumers (Vieira et al., 2001). Worldwide, small-seed red lentils (microsperm type) and orange cotyledon are the most produced and commercialized worldwide, due to the international market demand, mainly from the Indian subcontinent (Rawal \& Bansal, 2019). However, this type of lentil has not been produced in Brazil yet.

International Center for Agricultural Research in the Dry Areas (ICARDA), holder of the largest collection of lentils in the world (Kumar et al., 2013), made available to Embrapa Hortaliças genotypes of macro and microsperm types, in order to expand the genetic basis and resume the breeding program for this species in Brazil. However, information about these genotypes are unavailable, and studies on morphological and agronomical characterization are necessary. These studies can contribute for the breeding program, identifying genotypes which present precocity, high yield, grain characteristics that meet the requirements of traders and consumers, adaptation to mechanized harvest and other agronomic traits of interest (Malhotra et al., 2019).

Studies on characterization and evaluation performed through observations (qualitative traits) and measurements (quantitative traits) using morphological descriptors are able to provide the first genetic variability estimates in the germplasm (Burle \& Oliveira, 2010), forming an important data basis which can subsidize genetic breeding for different purposes. Besides, using multivariate analysis techniques, based on dissimilarity measures, make it possible to evaluate, simultaneously in relation to several traits, the genetic divergence among the genotypes.

This study aimed to evaluate a set of lentil genotypes provided by ICARDA based on morpho-agronomic traits to identify promising genotypes which can be exploited in breeding programs.

\section{MATERIAL AND METHODS}

The experiments were carried out at Embrapa Hortaliças experimental field, Brasília-DF, (15 56'14'S, 4808'31'W, $1000 \mathrm{~m}$ altitude), during 2017 and 2018. According to Köppen (Kottek et al., 2006), the local climate is Aw type, with dry winter. The temperature during the crop cycle ranged from $27.4^{\circ} \mathrm{C}$ to $15.8^{\circ} \mathrm{C}$ (maximum and minimum, respectively) in 2017, and the temperature ranged from $27.4^{\circ} \mathrm{C}$ to $15.7^{\circ} \mathrm{C}$, in 2018 . Relative humidity in these two years was $55.6 \%$ and average rainfall was $1.7 \mathrm{~mm} /$ day (Inmet, 2018).

We evaluated 48 lentil genotypes from International Center for Agricultural Research in the Dry Areas (ICARDA). Cultivar Silvina was used as control (Embrapa Hortaliças, 2014) (Table 1). The soil was classified as Typic Hapludox, the chemical properties in 0-20 cm layer, in 2017, immediately before the beginning of the experiment were: $\mathrm{pH}($ water $)=5.2 ; \mathrm{pH}\left(\mathrm{CaCl}_{2}\right)=$ 5.2 ; organic matter $=3.0 \% ; \mathrm{P}_{\text {(Mehlich) }}=$ $2.9 \mathrm{mg} \mathrm{dm}^{-3} ; \mathrm{K}_{\text {(Mehlich) }}=191.59 \mathrm{mg} \mathrm{dm}^{-3}$; $\mathrm{Ca}_{(\mathrm{KCl})}=0.5 \mathrm{cmol}_{\mathrm{c}} \mathrm{dm}^{-3} ; \mathrm{Mg}_{(\mathrm{KCl})}=0.5$ $\mathrm{cmol}_{\mathrm{c}} \mathrm{dm}^{-3} ; \mathrm{Al}$ (Mehlich) $=0.9 \mathrm{cmol}_{\mathrm{c}} \mathrm{dm}^{3}$; $\mathrm{H}+\mathrm{Al}{ }_{(\mathrm{SMP})}=4.3 \mathrm{cmol}_{\mathrm{c}} \mathrm{dm}^{-3}$; cation exchange capacity at $\mathrm{pH} 7.0(\mathrm{CEC})=5.8$ $\mathrm{cmol}_{\mathrm{c}} \mathrm{dm}^{-3}$; base saturation $(\mathrm{V})=27 \%$; aluminum saturation $(\mathrm{m})=37 \%$; $\mathrm{B}_{\text {(hot }}$ water) $=0.03 \mathrm{mg} \mathrm{dm}^{-3} ; \mathrm{Cu}_{\text {(Mehlich) }}=1.60 \mathrm{mg}$ $\mathrm{dm}^{-3} ; \mathrm{Fe}_{\text {(Mehlich) }}=84 \mathrm{mg} \mathrm{dm}^{-3} ; \mathrm{Mn}_{\text {(Mehlich) }}=$ $22.3 \mathrm{mg} \mathrm{dm}^{-3} ; \mathrm{Zn}_{\text {(Mehlich) }}=1.90 \mathrm{mg} \mathrm{dm}^{-3}$; $\mathrm{S}_{[\mathrm{Ca}(\mathrm{H} 2 \mathrm{PO} 4) 2]}=2.6 \mathrm{mg} \mathrm{dm}^{-3}$.

The experimental design was randomized blocks with 49 treatments (48 inbred lines and cultivar Silvina), with two replicates in 2017 and three replicates in 2018. The plots consisted of one 4-meter-long row, considering two planting rows, spaced $0.50 \mathrm{~m}$ between each other, with 10 plants each, totalizing a useful area of $2.0 \mathrm{~m}^{2}$ per plot. Sowings were carried out in the same area on May $10^{\text {th }}$ and May $24^{\text {th }}, 2017$ and 2018, respectively, 30 days after application of $2000 \mathrm{~kg} \mathrm{ha}^{-1}$ of dolomitic limestone (PRNT 80\%), in each of the years, based on the level of base saturation showed by the chemical analysis of the first experimental year. In both experiments, sowing fertilization was carried out using $16 \mathrm{~kg} \mathrm{ha}^{-1} \mathrm{~N}, 120$ $\mathrm{kg} \mathrm{ha}^{-1} \mathrm{P}_{2} \mathrm{O}_{5}$ and $64 \mathrm{~kg} \mathrm{ha}^{-1} \mathrm{~K}_{2} \mathrm{O}$ in the furrows. Seeds were not inoculated with Rhizobium sp. Top-dressing fertilization was performed at 30 days after emergence (DAE) with application of $100 \mathrm{~kg} \mathrm{ha}^{-1} \mathrm{~N}$ (urea) (Vieira, 2003).

We used sprinkler irrigation system, with a daily gross water depth (from 5 to $6 \mathrm{~mm}$ ) according to Giordano et al. (1988) recommendation, applied at more frequent intervals during the emergence period until the plants were fully developed. The irrigation was temporarily suspended in two cycle stages: before the beginning of flowering and at the end of the grain filling. This practice is carried out in order to stimulate grain production and maturation, respectively (Vieira \& Lima, 2016). A sensor-based device (tensiometer $40 \mathrm{Kpa}$, brand Irrigas ${ }^{\circledR}$, model HID02) determined the irrigation shifts. The gadget was installed at two depths (15 and $30 \mathrm{~cm}$ ) (Marouelli \& Calbo, 2009).

Weeds were controlled by hand hoeing throughout the crop cycle. Insecticides and fungicides were not applied, despite some insect-pest had been found in the experiment, such as caterpillars, thrips, aphids, mining larvae and bedbugs, without species identification, and diseases (soil fungus and powdery mildew).

\section{Morpho-agronomic characterization}

Genotype characterization was carried out based on fifteen descriptors established by International Union for the Protection of new Varieties of Plants (UPOV, 2015), nine being qualitative traits (growth habit, anthocyanin pigmentation in stem, branching 
intensity, leaf color intensity, leaflet shape, flower color, violet streaks on the flower, seed coating color and cotyledon color) and six quantitative traits (number of days until flowering starts, plant height, pod length, seed width and weight of 1000 seeds). Additionally, information was collected on the following quantitative traits: height of the first pod insertion (evaluated at the beginning of the reproductive phase, using a graduated ruler, between the ground level and the first pod of the lower third of the plant), number of pods per plant (counting the number of pods per plant), number of seeds per plant (counting the total number of seeds per plant), seed yield per plant (seed weight, in grams, per plant), productivity (total weight of seeds per plot, in grams) and cycle duration (counting the number of days from sowing to harvest).

\section{Grouping analysis}

In order to get information using morpho-agronomic variables, the authors performed multivariate analysis using cluster method (Cruz et al., 2012). Qualitative and quantitative variables have been transformed into binary data. Using these data, the dissimilarity values were calculated using Jaccard's coefficient and projected in a dendrogram created using Unweighted Pair-Group Method Arithmetic Average (UPGMA). Besides, Tocher's optimized method was used to verify coherence of the groups formed in the dendrogram.

\section{Statistical analysis}

For qualitative descriptors, the percentual frequencies of each category were calculated and, for quantitative traits, the experimental data were submitted to individual and joint variance analysis, using $\mathrm{F}$ test. The authors needed to transform number of pods per plant, number of seeds per plant, seed yield and weight of 1000 seeds to $\sqrt{x+0.5}$ and productivity to $\log (x+0.5)$ assumptions of the analysis of variance. The joint analysis was carried out under conditions of homogeneity of residual variances (Pimentel-Gomes, 2009), using SAS 9.2 software (SAS, 2009). When inbred line $x$ year interaction was significant, the authors decided to unfold this interaction and the average test of double-entry table average test was performed with adjusted averages using the Scott-Knott clustering $(\mathrm{p} \leq 0.05)$, with the aid of Genes software (Cruz, 2013).

\section{RESULTS AND DISCUSSION}

\section{Qualitative traits}

Percentage frequency distribution of qualitative traits showed variations among the studied genotypes (48 inbred lines + cultivar Silvina). Semi-erect growth habit was verified in $46.9 \%$ of genotypes, followed by erect growth habit $(40.9 \%)$ and by prostrate growth habit $(12.2 \%)$. Only $8.2 \%$ of genotypes showed anthocyanin pigmentation in the stem, which was completely absent (green stem) for the rest $91.8 \%$.

For branching intensity, $91.8 \%$ of genotypes showed the strong variant, whereas the weak variant was verified in $8.2 \%$ genotypes. The leaf color intensity for medium-green hue was predominant $(91.8 \%)$, whereas strong green color occurred in $8.2 \%$ of the genotypes. The authors observed that the difference between the leaf color intensity variant might have been influenced by luminosity at the moment of evaluation, as well as by soil nitrogen level (Ferreira et al., 2011). The oval leaflet shape $(59.2 \%)$ predominated in relation to the elliptical one (40.8\%).

White flowers were observed in $97.9 \%$ of the genotypes. Only FLIP2009$15 \mathrm{~L}$ showed light pink flowers. This trait is important for verifying the varietal purity (Roy et al., 2012), since the parameter "flower color" can vary depending on the genotype, flower age and environmental conditions (Sharma, 2009). All the genotypes showed violet streaks on the flowers.

Red-coated seeds showing orange cotyledon were found in 43 genotypes $(87.8 \%)$. Green coating was observed in $12.2 \%$ and green cotyledon in $10.2 \%$ of the genotypes. Only cultivar Silvina showed yellow cotyledon.

\section{Quantitative traits}

Quantitative traits evaluated in this study were influenced by genotypes and/or year of evaluation, showing significant differences $(\mathrm{p} \leq 0.05)$, except for plant height (Table 2). Significant interaction $(\mathrm{p} \leq 0.05)$ year $\mathrm{x}$ genotype was observed only for number of days until flowering beginning. Thus, studies on the unfolding of these factors were carried out (Table 3).

The number of days until the flowering beginning ranged from 50 to 107.5 in the first year (2017) and from 59 to 92 in the second year (2018) (Table 3). Vieira (2003), working with lentil genotypes from ICARDA, in Coimbra-MG, verified values similar to the ones found in this study for flowering beginning (60 and 102 days after sowing). Cultivar Silvina stood out among the genotypes in two years of evaluation, maintaining its earlyflowering pattern and presenting 50\% of the plants with, at least, one flower open at 50 days and 59 days in the first and second years, respectively. Genotype FLIP2010-20L did not differ from cultivar Silvina in the second year of the experiment, showing flowering beginning at 65 days. Genotypes 81S15, FLIP2007-28L, FLIP200774L, FLIP2007-77L, FLIP20092L, FLIP2009-4L, FLIP2009-7L, FLIP2009-15L, FLIP2009-18L, FLIP2009-27L, FLIP2010-19L and FLIP2010-21L flourished later in these two years. Comparing the two years of experiment, we observed a decrease in number of days for flowering beginning in 23 genotypes, with an average reduction of 8.5 days and 24.2 days in genotypes FLIP2010-32L and 6031, respectively (Table 3 ). Delayed sowing could have been the responsible for this result in the second year (14 days), since the average temperature of sowing up to flowering beginning were similar in both years $\left(\max .26 .4^{\circ} \mathrm{C}\right.$ and $\min .14 .8^{\circ} \mathrm{C}$ in 2017 ; $\max .26 .6^{\circ} \mathrm{C}$ and $\min .14 .3^{\circ} \mathrm{C}$ in 2018).

No significant effect concerning genotypes and year for plant height was noticed (Table 2). Despite this, all genotypes showed a numerical value for plant height above the value obtained by cultivar Silvina (Table 3 ). Lentil plants can vary from 20 to $75 \mathrm{~cm}$ high, depending on the genotype and growing conditions (Saxena, 2009).

In relation to insertion height of the 
Table 1. Identification, pedigree and origin of 48 lentil inbred lines (Lens culinaris) from International Center for Agricultural Research in the Dry Areas (ICARDA) and commercial cultivar Silvina. Brasília, Embrapa Hortaliças, 2020.

\begin{tabular}{|c|c|c|c|}
\hline $\mathbf{N}^{\mathbf{o}}$ & Genotype & Pedigree & Origin \\
\hline 01 & $81 \mathrm{~S} 15$ & UJL 197 x ILL 4400 & JORDAN \\
\hline 02 & FLIP90-25L & ILL 5588 x ILL 99 & ICARDA \\
\hline 03 & FLIP2007-11L & ILL 2126 x ILL 1005 & ICARDA \\
\hline 04 & FLIP2007-16L & ILL 2126 x ILL 4659 & ICARDA \\
\hline 05 & FLIP2007-28L & ILL 590 x ILL 5769 & ICARDA \\
\hline 06 & FLIP2007-42L & ILL 7201 x ILL 5728 & ICARDA \\
\hline 07 & FLIP2007-74L & ILL 590 x ILL 6434 & ICARDA \\
\hline 08 & FLIP2007-75L & ILL 590 x ILL 1005 & ICARDA \\
\hline 09 & FLIP2007-77L & ILL 1939 x ILL 8090 & ICARDA \\
\hline 10 & FLIP2008-2L & ILL 857 x AKM 362 & ICARDA \\
\hline 11 & FLIP2009-1L & ILL 7620 x ILL 7686 & ICARDA \\
\hline 12 & FLIP2009-2L & ILL 7620 x ILL 7686 & ICARDA \\
\hline 13 & FLIP2009-4L & ILL $6991 \times$ ILL 7686 & ICARDA \\
\hline 14 & FLIP2009-5L & ILL $6991 \times$ ILL 7686 & ICARDA \\
\hline 15 & FLIP2009-7L & ILL 5883 x ILL 7706 & ICARDA \\
\hline 16 & FLIP2009-9L & ILL 7502 x ILL 6994 & ICARDA \\
\hline 17 & FLIP2009-10L & ILL 7502 x ILL 6994 & ICARDA \\
\hline 18 & FLIP2009-11L & ILL 8077 x ILL 6994 & ICARDA \\
\hline 19 & FLIP2009-12L & ILL 8077 x ILL 6994 & ICARDA \\
\hline 20 & FLIP2009-13L & ILL 8077 x ILL 6994 & ICARDA \\
\hline 21 & FLIP2009-14L & ILL 8077 x ILL 6994 & ICARDA \\
\hline 22 & FLIP2009-15L & ILL $6778 \times$ ILL 6994 & ICARDA \\
\hline 23 & FLIP2009-16L & ILL $5588 \times$ ILL 7979 & ICARDA \\
\hline 24 & FLIP2009-17L & ILL $5588 \times$ ILL 8188 & ICARDA \\
\hline 25 & FLIP2009-18L & ILL 5883 x ILL 6994 & ICARDA \\
\hline 26 & FLIP2009-19L & ILL 5883 x ILL 6994 & ICARDA \\
\hline 27 & FLIP2009-25L & ILL 5883 x ILL 6994 & ICARDA \\
\hline 28 & FLIP2009-26L & ILL 5883 x ILL 6994 & ICARDA \\
\hline 29 & FLIP2009-27L & ILL 5883 x ILL 6994 & ICARDA \\
\hline 30 & FLIP2010-2L & ILL 2126 x ILL 4637 & ICARDA \\
\hline 31 & FLIP2010-8L & ILL 2126 x ILL 6199 & ICARDA \\
\hline 32 & FLIP2010-12L & ILL 6199 x ILL 2126 & ICARDA \\
\hline 33 & FLIP2010-19L & ILL 0590 x ILL 5769 & ICARDA \\
\hline 34 & FLIP2010-20L & ILL $0590 \times$ ILL 5769 & ICARDA \\
\hline 35 & FLIP2010-21L & ILL $7012 \times$ ILL 2125 & ICARDA \\
\hline 36 & FLIP2010-22L & ILL $7012 \times$ ILL 2125 & ICARDA \\
\hline 37 & FLIP2010-23L & ILL $7012 \times$ ILL 2125 & ICARDA \\
\hline 38 & FLIP2010-24L & ILL 2126 x ILL 6199 & ICARDA \\
\hline 39 & FLIP2010-27L & ILL 6024 x ILL 0098 & ICARDA \\
\hline 40 & FLIP2010-28L & ILL 8090 x ILL 6783 & ICARDA \\
\hline 41 & FLIP2010-29L & ILL 8090 x ILL 6783 & ICARDA \\
\hline 42 & FLIP2010-30L & ILL 8090 x ILL 7685 & ICARDA \\
\hline 43 & FLIP2010-31L & ILL 8090 x ILL 7685 & ICARDA \\
\hline 44 & FLIP2010-32L & ILL 8090 x ILL 7685 & ICARDA \\
\hline 45 & FLIP2010-99L & ILL 7620 x 91517 & ICARDA \\
\hline 46 & FLIP2010-100L & ILL 2501 x ILL 5737 & ICARDA \\
\hline 47 & FLIP2010-106L & ILL 7723 x ILX 87062 & ICARDA \\
\hline 48 & SILVINA & - & EMBRAPA \\
\hline 49 & 6031 & ILL $101 \times$ ILL 162 & ICARDA \\
\hline
\end{tabular}

first pod, no significant difference was observed among the genotypes, the lowest numerical value being observed for the cultivar Silvina, $16.82 \mathrm{~cm}$. Lentil plants with pods from 10 to 15 $\mathrm{cm}$ high in relation to soil can favor a better phytosanitary state of the seeds and less loss in mechanized harvest (Diekmann \& Al-Saleh, 2009). Thus, all the genotypes showed appropriate standard for this trait.

Genotypes FLIP2010-27L, FLIP2010-100L, FLIP2009-19L, FLIP2009-11L, FLIP2010-106L and FLIP2009-1L made up the group with the highest average for the number of pods per plant (Table 3 ). The longest pods were obtained by cultivar Silvina (14.42 mm), differing statistically from the genotypes. However, in relation to pod width, the genotypes FLIP2010-2L and FLIP 2010-19L (7.27 $\mathrm{mm})$, FLIP2007-11L (7.68 $\mathrm{mm})$ and FLIP2007-16L (7.40 mm) did not differ statistically from cultivar Silvina (7.96 $\mathrm{mm})$. For seed yield per plant, these four genotypes differed statistically from cultivar Silvina, though.

Genotypes FLIP2007-11L, FLIP2010-2L, FLIP2010-19L and cultivar Silvina showed larger seeds, this being different from the others (Table 3). Cultivar Silvina showed the greatest weight of one thousand seeds $(53.47 \mathrm{~g})$, followed by genotypes FLIP 2007-16L (52.11 g), FLIP 20102L (49.70 g), FLIP 2007-11L (48.63 g), FLIP 2010-8L (48.55 g) and FLIP 2010-12L (43.45 g). The genotype FLIP 2009-15L showed the lowest weight (20.59 g) (Table 3).

In relation to productivity, Silvina is considered one of the most productive cultivar, showing much superior average productivity $\left(2.259 \mathrm{~kg} \mathrm{ha}^{-1}\right)$ in relation to worldwide average (1.042 $\mathrm{kg} \mathrm{ha}^{-1}$ ) (Faostat, 2020). Cultivar Silvina and the genotype 6031 showed to be earlier in terms of cycle length; twelve genotypes showed intermediate cycle and 35 genotypes late cycle (Table 3 ).

\section{Genetic divergence}

Considering 21 evaluated morphogenetic traits, a dendrogram was created (Figure 1) showing the formation of five groups, at $40 \%$ similarity level, obtaining an acceptable cophenetic 
Table 2. Summary of the joint analysis of variance for quantitative morpho-agronomic traits of 48 lentil inbred lines (Lens culinaris) and the commercial cultivar Silvina in two years, 2017 and 2018. Brasília, Embrapa Hortaliças, 2020.

\begin{tabular}{|c|c|c|c|c|c|c|c|c|c|c|c|c|c|}
\hline \multirow[b]{2}{*}{ FV } & \multirow[b]{2}{*}{ GL } & \multicolumn{10}{|c|}{ Medium square } & \multirow[b]{2}{*}{ PROD } & \multirow[b]{2}{*}{ CI } \\
\hline & & NDIF & APLA & IVAG & CVAG & LVAG & NVAG & NSEM & RSEM & LSEM & P1000 & & \\
\hline Year (A) & 1 & $2777.77^{* *}$ & $14.86^{\mathrm{ns}}$ & $2488.72^{* *}$ & $4.35^{\mathrm{ns}}$ & $4.61^{\mathrm{ns}}$ & $382.97^{* *}$ & $201.92^{* *}$ & $2.92^{* *}$ & $9.83^{* *}$ & $67.36^{* *}$ & $0.10^{\mathrm{ns}}$ & $0.00^{\mathrm{ns}}$ \\
\hline Genotype (G) & 48 & $11147.82^{* *}$ & $3244.22^{\text {ns }}$ & $1549.05^{\mathrm{ns}}$ & $343.91^{* *}$ & $72.92^{* *}$ & $698.99^{\mathrm{ns}}$ & $714.48^{* *}$ & $19.35^{* *}$ & $60.66^{* *}$ & $144.50^{\mathrm{ns}}$ & $7.04^{* *}$ & $6891.89^{* *}$ \\
\hline $\mathrm{A} \times \mathrm{G}$ & 47 & $4297.19^{* *}$ & $2167.32^{\text {ns }}$ & $1214.88^{\mathrm{ns}}$ & $60.53^{\mathrm{ns}}$ & $19.42^{\mathrm{ns}}$ & $253.66^{\mathrm{ns}}$ & $142.83^{\mathrm{ns}}$ & $3.42^{\mathrm{ns}}$ & $18.84^{\mathrm{ns}}$ & $79.71^{\mathrm{ns}}$ & $2.43^{\mathrm{ns}}$ & $1422.66^{\mathrm{ns}}$ \\
\hline Averages & & 85.25 & 49.84 & 25.07 & 10.38 & 6.17 & 73.06 & 46.44 & 1.38 & 4.29 & 5.43 & 307.0 & 143.94 \\
\hline $\mathrm{CV}(\%)$ & & 7.03 & 12.38 & 17.58 & 10.58 & 8.91 & 31.14 & 32.67 & 23.08 & 17.30 & 13.05 & 22.40 & 4.95 \\
\hline
\end{tabular}

${ }^{\text {ns }}$ non-significant $(\mathrm{p}<5 \%)$; ** significant $(\mathrm{p}<5 \%)$, by the $\mathrm{F}$ test; $\mathrm{FV}=$ variation source; $\mathrm{GL}=$ degrees of freedom; NDIF= number of days until flowering; APLA= plant height; IVAG= height of the first pod insertion; $C V A G=$ pod length; LVAG= pod width; $N V A G=$ number of pods per plant; NSEM= number of seeds per plant; RSEM= seed yield; LSEM= seed width; P1000= weight of 1000 seeds; PROD= productivity and $\mathrm{CI}=$ crop cycle duration.

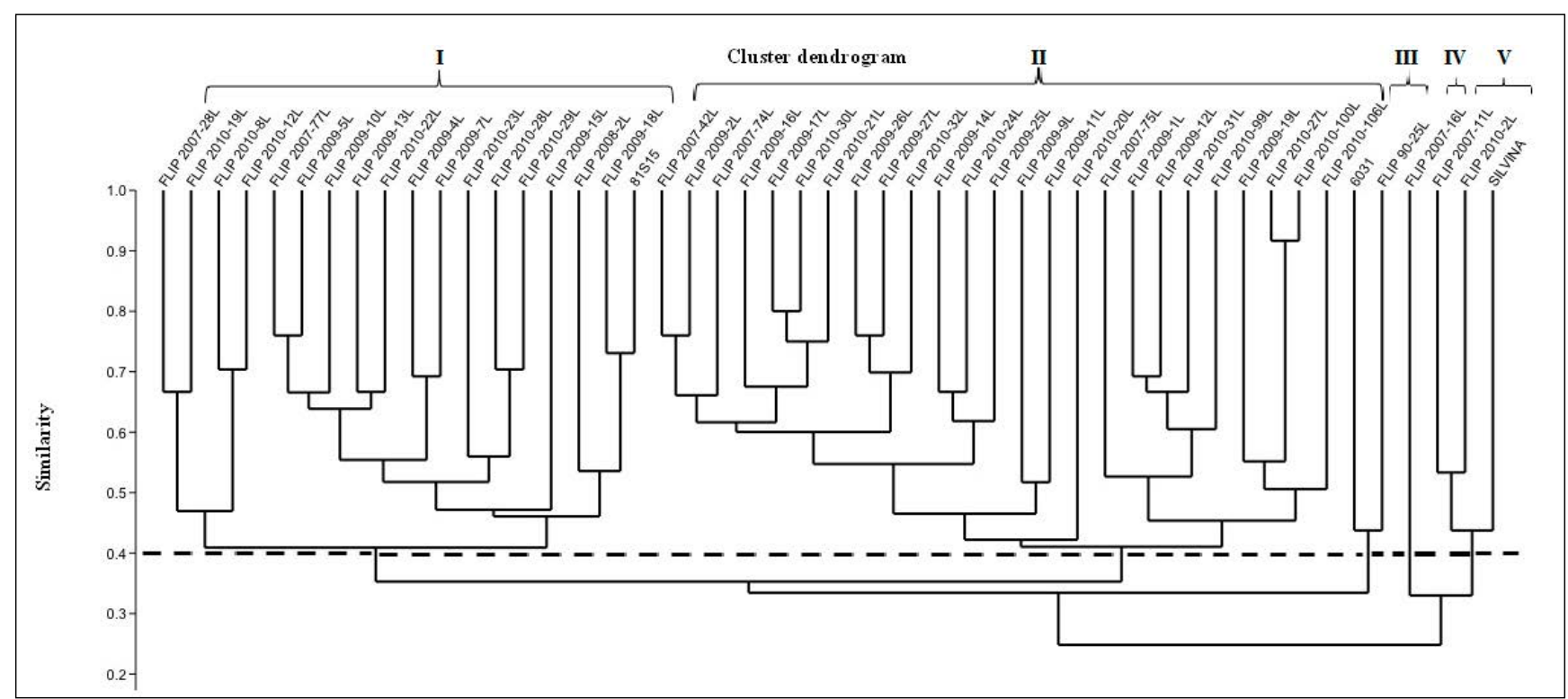

Figure 1. Dendrogram based on the UPGMA grouping of 48 lentil inbred lines (Lens culinaris) and commercial cultivar Silvina, based on 21 morpho-agronomic traits. Brasília, Embrapa Hortaliças, 2020.

coefficient (0.76). Groups I to III were composed of inbred lines classified as microsperm, showing red coating color of the seed and orangish cotyledon, and groups IV and V by macrosperm genotypes, with green-coated seeds and green and yellow cotyledons.

Group I consisted of 18 genotypes, these being most genotypes which showed erect growth habit, average branching intensity, the highest plants, height of the first pod insertion and 1000 seed weight among microsperms. Group II consisted of 25 genotypes, the majority with a semi-erect growth habit, strong branching intensity, medium color intensity of the leaf, the largest variations in leaflet shape considering oval and elliptical, the lowest average number of days until flowering beginning among microsperms, the highest averages for pod length and width, number of seeds per plant, seed yield and width. Group II included the most productive genotype among microsperms (FLIP 2010-99L).

Group III consisted of two genotypes with the smallest seed width among microsperms and the earliest cycle. The average productivity of this group was $410.84 \mathrm{~kg} \mathrm{ha}^{-1}$, the highest productivity compared with groups I and II.

The genotype in group IV showed semi-erect growth habit, branching intensity and intensity of the leaf color characterized as strong, seeds coated with green cotyledons.

Group V, composed of three genotypes, showed similarity varying from 35\% (FLIP2007-16L in relation to others) to $55 \%$ (FLIP2007-11L and FLIP2010-2L), with genotypes showing erect growth habit. Genotypes FLIP2007-11L and cultivar Silvina presented anthocyanin pigmentation in the stems, green-coated seeds, green (FLIP2007-11L and FLIP2010-2L) and yellow (Silvina) cotyledons, the longest and widest pods, the greatest number of seeds per plant, the highest seed yield per plant and the highest productivity. This group also presented the earliest genotype among those of macrosperm type, it means, cultivar Silvina.

Partial coincidence was observed among groups formed by Tocher's test and by the dendrogram. Six groups were formed by the Tocher's method (Table 4), and five groups were obtained by cutting the dendrogram (Figure 1). 
Table 3. Average values of the number of days until flowering (NDIF), plant height (APLA), height of first pod insertion (IVAG), pod length (CVAG), pod width (LVAG), number of pods per plant (NVAG), number of seeds per plant (NSEM), seed yield per plant (RSEM), seed width (LSEM), weight of 1000 seeds (P1000), productivity (PROD) crop cycle duration (CI) of 48 lentil inbred lines and cultivar Silvina in two years, 2017 and 2018. Brasília, Embrapa Hortaliças, 2020.

\begin{tabular}{|c|c|c|c|c|c|c|c|c|}
\hline \multirow{2}{*}{$\mathbf{N}$} & \multirow{2}{*}{ Genotype } & \multicolumn{2}{|c|}{ NDIF (Years) } & \multirow{2}{*}{$\begin{array}{c}\text { APLA } \\
(\mathrm{cm})\end{array}$} & \multirow{2}{*}{$\begin{array}{l}\text { IVAG } \\
(\mathrm{cm})\end{array}$} & \multirow{2}{*}{$\begin{array}{c}\text { CVAG } \\
(\mathrm{mm})\end{array}$} & \multirow{2}{*}{$\begin{array}{c}\text { LVAG } \\
(\mathrm{mm})\end{array}$} & \multirow{2}{*}{ NVAG } \\
\hline & & 2017 & 2018 & & & & & \\
\hline 1 & $81 \mathrm{~S} 15$ & $93.0 \mathrm{aA}$ & $92.0 \mathrm{aA}$ & 51.80 & 26.45 & $9.78 \mathrm{e}$ & $6.27 \mathrm{c}$ & 34.18 \\
\hline 2 & FLIP90-25L & $84.0 \mathrm{bA}$ & $79.0 \mathrm{bA}$ & 49.40 & 26.59 & $9.08 \mathrm{f}$ & $5.65 d$ & 103.79 \\
\hline 3 & FLIP2007-11L & $89.5 \mathrm{aA}$ & $79.0 \mathrm{bB}$ & 48.48 & 25.40 & $13.38 b$ & $7.68 \mathrm{a}$ & 78.69 \\
\hline 4 & FLIP2007-16L & $73.5 \mathrm{bA}$ & $77.0 \mathrm{bA}$ & 50.78 & 26.95 & $13.04 \mathrm{~b}$ & $7.40 \mathrm{a}$ & 34.61 \\
\hline 5 & FLIP2007-28L & $93.0 \mathrm{aA}$ & $92.0 \mathrm{aA}$ & 48.21 & 26.09 & $11.98 \mathrm{c}$ & $7.15 b$ & 46.06 \\
\hline 6 & FLIP2007-42L & $82.5 \mathrm{bB}$ & $87.0 \mathrm{aA}$ & 52.52 & 26.66 & $10.27 \mathrm{e}$ & $6.17 \mathrm{c}$ & 65.29 \\
\hline 7 & FLIP2007-74L & $89.5 \mathrm{aA}$ & $92.0 \mathrm{aA}$ & 56.48 & 26.13 & $10.05 \mathrm{e}$ & $6.29 \mathrm{c}$ & 57.33 \\
\hline 8 & FLIP2007-75L & $84.0 \mathrm{bA}$ & $79.0 \mathrm{bA}$ & 53.59 & 26.66 & $10.30 \mathrm{e}$ & $6.43 c$ & 83.92 \\
\hline 9 & FLIP2007-77L & $98.5 \mathrm{aA}$ & $92.0 \mathrm{aA}$ & 52.56 & 29.60 & $9.57 f$ & $5.70 \mathrm{~d}$ & 39.09 \\
\hline 10 & FLIP2008-2L & $84.0 \mathrm{bA}$ & $80.0 \mathrm{bA}$ & 52.70 & 32.68 & $10.13 \mathrm{e}$ & $6.27 \mathrm{c}$ & 63.80 \\
\hline 11 & FLIP2009-1L & $79.0 \mathrm{bA}$ & $79.0 \mathrm{bA}$ & 52.35 & 20.58 & $11.07 \mathrm{~d}$ & $6.67 \mathrm{~b}$ & 144.88 \\
\hline 12 & FLIP2009-2L & $95.0 \mathrm{aA}$ & $92.0 \mathrm{aA}$ & 46.88 & 25.08 & $10.66 \mathrm{e}$ & $6.30 \mathrm{c}$ & 69.12 \\
\hline 13 & FLIP2009-4L & $95.0 \mathrm{aA}$ & $90.5 \mathrm{aA}$ & 53.51 & 26.95 & $8.86 f$ & $5.85 \mathrm{c}$ & 99.73 \\
\hline 14 & FLIP2009-5L & $97.0 \mathrm{aA}$ & $79.0 \mathrm{bB}$ & 56.35 & 26.60 & $8.98 \mathrm{f}$ & $5.68 \mathrm{~d}$ & 28.87 \\
\hline 15 & FLIP2009-7L & $95.0 \mathrm{aA}$ & $91.0 \mathrm{aA}$ & 50.89 & 28.44 & $9.13 f$ & $5.89 \mathrm{c}$ & 54.41 \\
\hline 16 & FLIP2009-9L & $98.5 \mathrm{aA}$ & $85.5 \mathrm{bB}$ & 50.41 & 23.84 & $8.17 \mathrm{~g}$ & $5.25 \mathrm{e}$ & 105.68 \\
\hline 17 & FLIP2009-10L & $93.0 \mathrm{aA}$ & $81.0 \mathrm{bB}$ & 50.39 & 28.16 & $8.71 \mathrm{f}$ & $5.49 \mathrm{~d}$ & 70.55 \\
\hline 18 & FLIP2009-11L & $77.5 \mathrm{bA}$ & $79.7 \mathrm{bA}$ & 42.44 & 22.06 & $9.40 \mathrm{f}$ & $5.74 d$ & 153.10 \\
\hline 19 & FLIP2009-12L & $78.5 \mathrm{bA}$ & $80.3 \mathrm{bA}$ & 50.93 & 23.35 & $11.01 \mathrm{~d}$ & $6.09 \mathrm{c}$ & 110.77 \\
\hline 20 & FLIP2009-13L & $95.0 \mathrm{aA}$ & $83.3 \mathrm{bB}$ & 52.18 & 26.30 & $9.46 f$ & $5.97 \mathrm{c}$ & 66.74 \\
\hline 21 & FLIP2009-14L & $91.5 \mathrm{aA}$ & $80.0 \mathrm{bB}$ & 48.65 & 24.20 & $10.09 \mathrm{e}$ & $5.86 \mathrm{c}$ & 90.30 \\
\hline 22 & FLIP2009-15L & $91.5 \mathrm{aA}$ & $92.0 \mathrm{aA}$ & 49.76 & 24.52 & $8.90 \mathrm{f}$ & $5.23 \mathrm{e}$ & 49.37 \\
\hline 23 & FLIP2009-16L & $98.5 \mathrm{aA}$ & $77.0 \mathrm{bB}$ & 50.01 & 23.84 & $9.53 f$ & $5.26 \mathrm{e}$ & 58.05 \\
\hline 24 & FLIP2009-17L & $91.5 \mathrm{aA}$ & $77.3 \mathrm{bB}$ & 53.21 & 25.18 & $10.78 \mathrm{e}$ & $6.39 \mathrm{c}$ & 62.60 \\
\hline 25 & FLIP2009-18L & $93.5 \mathrm{aA}$ & $92.0 \mathrm{aA}$ & 50.80 & 27.60 & $9.85 \mathrm{e}$ & $6.19 \mathrm{c}$ & 38.39 \\
\hline 26 & FLIP2009-19L & $91.5 \mathrm{aA}$ & $79.0 \mathrm{bB}$ & 43.83 & 19.50 & $9.95 \mathrm{e}$ & $6.53 c$ & 160.50 \\
\hline 27 & FLIP2009-25L & $98.5 \mathrm{aA}$ & $79.0 \mathrm{bB}$ & 46.91 & 23.66 & $9.86 \mathrm{e}$ & $6.07 \mathrm{c}$ & 104.54 \\
\hline 28 & FLIP2009-26L & $95.0 \mathrm{aA}$ & $83.5 \mathrm{bB}$ & 50.45 & 22.53 & $9.56 f$ & $6.12 \mathrm{c}$ & 86.54 \\
\hline 29 & FLIP2009-27L & $93.0 \mathrm{aA}$ & $92.0 \mathrm{aA}$ & 56.64 & 25.36 & $9.36 f$ & $6.11 \mathrm{c}$ & 65.41 \\
\hline 30 & FLIP2010-2L & $95.0 \mathrm{aA}$ & $81.0 \mathrm{bB}$ & 49.82 & 24.36 & $12.31 \mathrm{c}$ & $7.27 \mathrm{a}$ & 55.25 \\
\hline 31 & FLIP2010-8L & $95.0 \mathrm{aA}$ & $80.5 \mathrm{bB}$ & 57.11 & 26.50 & $11.92 \mathrm{c}$ & $6.61 b$ & 28.51 \\
\hline 32 & FLIP2010-12L & $101.5 \mathrm{aA}$ & $78.3 \mathrm{bB}$ & 47.27 & 26.78 & $12.43 \mathrm{c}$ & $6.92 b$ & 36.15 \\
\hline 33 & FLIP2010-19L & $93.0 \mathrm{aA}$ & $87.0 \mathrm{aA}$ & 49.82 & 24.36 & $12.31 \mathrm{c}$ & $7.27 \mathrm{a}$ & 55.25 \\
\hline 34 & FLIP2010-20L & $88.0 \mathrm{aA}$ & $65.0 \mathrm{cB}$ & 57.11 & 26.50 & $11.92 \mathrm{c}$ & $6.61 b$ & 28.51 \\
\hline 35 & FLIP2010-21L & $93.0 \mathrm{aA}$ & $88.7 \mathrm{aA}$ & 47.27 & 26.78 & $12.43 \mathrm{c}$ & $6.92 b$ & 36.15 \\
\hline 36 & FLIP2010-22L & $91.5 \mathrm{aA}$ & $77.0 \mathrm{bB}$ & 46.60 & 24.85 & $9.11 \mathrm{f}$ & $5.75 d$ & 47.73 \\
\hline 37 & FLIP2010-23L & $100.5 \mathrm{aA}$ & $83.7 \mathrm{bB}$ & 53.14 & 25.87 & $9.56 f$ & $6.02 \mathrm{c}$ & 45.75 \\
\hline 38 & FLIP2010-24L & $77.5 \mathrm{bA}$ & $82.3 \mathrm{bA}$ & 48.03 & 22.82 & $10.28 \mathrm{e}$ & $6.25 c$ & 66.10 \\
\hline 39 & FLIP2010-27L & $74.5 \mathrm{bA}$ & $79.0 \mathrm{bA}$ & 44.14 & 22.64 & $10.77 \mathrm{e}$ & $6.38 \mathrm{c}$ & 182.92 \\
\hline 40 & FLIP2010-28L & $101.5 \mathrm{aA}$ & $82.0 \mathrm{bB}$ & 51.79 & 26.42 & $7.46 \mathrm{~g}$ & $4.62 \mathrm{e}$ & 45.42 \\
\hline 41 & FLIP2010-29L & $95.0 \mathrm{aA}$ & $84.3 \mathrm{bB}$ & 51.24 & 25.56 & $9.33 \mathrm{f}$ & $5.69 \mathrm{~d}$ & 82.50 \\
\hline 42 & FLIP2010-30L & $89.5 \mathrm{aA}$ & $79.0 \mathrm{bB}$ & 52.48 & 22.43 & $9.82 \mathrm{e}$ & $6.25 c$ & 87.47 \\
\hline 43 & FLIP2010-31L & $93.0 \mathrm{aA}$ & $72.3 \mathrm{bB}$ & 49.52 & 23.33 & $10.93 d$ & $6.13 c$ & 103.65 \\
\hline 44 & FLIP2010-32L & $87.5 \mathrm{aA}$ & $79.0 \mathrm{bB}$ & 50.97 & 26.08 & $9.64 f$ & $6.03 c$ & 93.46 \\
\hline 45 & FLIP2010-99L & $79.5 \mathrm{bA}$ & $76.0 \mathrm{bA}$ & 45.03 & 21.10 & $10.74 \mathrm{e}$ & $6.34 \mathrm{c}$ & 114.38 \\
\hline 46 & FLIP2010-100L & $82.5 \mathrm{bA}$ & $85.5 \mathrm{bA}$ & 40.15 & 20.70 & $10.52 \mathrm{e}$ & $5.90 \mathrm{c}$ & 173.68 \\
\hline 47 & FLIP2010-106L & $71.0 \mathrm{bA}$ & $81.7 \mathrm{bA}$ & 49.99 & 19.94 & $11.47 \mathrm{~d}$ & $5.81 \mathrm{~d}$ & 148.23 \\
\hline 48 & SILVINA & $50.0 \mathrm{cB}$ & $59.0 \mathrm{cA}$ & 37.70 & 16.82 & $14.42 \mathrm{a}$ & $7.96 \mathrm{a}$ & 81.24 \\
\hline 49 & 6031 & $107.5 \mathrm{aA}$ & $83.3 \mathrm{bB}$ & 43.71 & 23.55 & $11.34 \mathrm{~d}$ & $5.63 \mathrm{~d}$ & 64.01 \\
\hline
\end{tabular}


Table 3. continuation

\begin{tabular}{|c|c|c|c|c|c|c|c|}
\hline $\mathbf{N}$ & Genotype & NSEM & $\begin{array}{c}\text { RSEM } \\
\left(\text { g plant }^{-1}\right)\end{array}$ & $\begin{array}{c}\text { LSEM } \\
(\mathrm{mm})\end{array}$ & $\begin{array}{c}\text { P1000 } \\
\left(\mathrm{g} 1000^{-1}\right)\end{array}$ & $\begin{array}{l}\text { PROD } \\
\left(\mathrm{kg} \mathrm{ha}^{-1}\right)\end{array}$ & $\begin{array}{c}\text { CI } \\
\text { (days) }\end{array}$ \\
\hline 1 & $81 \mathrm{~S} 15$ & $19.57 \mathrm{~d}$ & $0.47 \mathrm{~d}$ & $4.30 \mathrm{c}$ & 28.04 & $143.48 b$ & $143 a$ \\
\hline 2 & FLIP90-25L & $68.06 \mathrm{~b}$ & $1.64 \mathrm{c}$ & $3.88 \mathrm{~d}$ & 26.12 & $604.40 \mathrm{a}$ & $137 b$ \\
\hline 3 & FLIP2007-11L & $46.68 \mathrm{c}$ & $2.06 \mathrm{~b}$ & $5.79 a$ & 48.63 & $433.73 a$ & $140 \mathrm{~b}$ \\
\hline 4 & FLIP2007-16L & $26.38 d$ & $1.13 \mathrm{c}$ & $5.13 b$ & 52.11 & $294.48 \mathrm{a}$ & $144 a$ \\
\hline 5 & FLIP2007-28L & $23.60 \mathrm{~d}$ & $0.97 \mathrm{~d}$ & $4.50 \mathrm{c}$ & 36.30 & $92.53 b$ & $145 \mathrm{a}$ \\
\hline 6 & FLIP2007-42L & $43.29 c$ & $1.16 \mathrm{c}$ & $4.50 \mathrm{c}$ & 32.14 & $222.55 b$ & $144 a$ \\
\hline 7 & FLIP2007-74L & $37.57 \mathrm{c}$ & $1.38 \mathrm{c}$ & $4.08 \mathrm{c}$ & 32.21 & $187.30 \mathrm{~b}$ & $148 \mathrm{a}$ \\
\hline 8 & FLIP2007-75L & $71.69 b$ & $2.71 b$ & $4.75 b$ & 32.82 & $335.64 a$ & $144 a$ \\
\hline 9 & FLIP2007-77L & $23.79 d$ & $0.50 \mathrm{~d}$ & $3.68 \mathrm{~d}$ & 25.09 & $74.85 b$ & $148 \mathrm{a}$ \\
\hline 10 & FLIP2008-2L & $29.72 d$ & $0.95 \mathrm{~d}$ & $4.44 c$ & 36.88 & $186.03 \mathrm{~b}$ & $140 \mathrm{~b}$ \\
\hline 11 & FLIP2009-1L & $89.55 b$ & $2.63 b$ & $4.51 \mathrm{c}$ & 28.99 & $399.68 \mathrm{a}$ & $147 \mathrm{a}$ \\
\hline 12 & FLIP2009-2L & $56.88 \mathrm{c}$ & $1.60 \mathrm{c}$ & $4.18 \mathrm{c}$ & 29.03 & $486.78 \mathrm{a}$ & $146 a$ \\
\hline 13 & FLIP2009-4L & $38.68 \mathrm{c}$ & $0.92 \mathrm{~d}$ & $4.03 c$ & 24.50 & $118.93 b$ & $149 a$ \\
\hline 14 & FLIP2009-5L & $7.59 \mathrm{~d}$ & $0.07 \mathrm{~d}$ & $3.57 \mathrm{~d}$ & 23.31 & $139.80 \mathrm{~b}$ & $150 \mathrm{a}$ \\
\hline 15 & FLIP2009-7L & $36.71 \mathrm{c}$ & $0.98 \mathrm{~d}$ & $4.21 \mathrm{c}$ & 26.20 & $229.38 b$ & $145 a$ \\
\hline 16 & FLIP2009-9L & $45.71 \mathrm{c}$ & $1.20 \mathrm{c}$ & $3.46 \mathrm{~d}$ & 21.21 & $42.65 b$ & $153 a$ \\
\hline 17 & FLIP2009-10L & $61.16 \mathrm{c}$ & $0.88 \mathrm{~d}$ & $3.58 \mathrm{~d}$ & 22.75 & $80.08 b$ & $142 \mathrm{a}$ \\
\hline 18 & FLIP2009-11L & $63.26 \mathrm{~b}$ & $1.62 \mathrm{c}$ & $4.12 \mathrm{c}$ & 23.10 & $290.68 b$ & $148 \mathrm{a}$ \\
\hline 19 & FLIP2009-12L & $79.62 b$ & $2.61 b$ & $4.51 \mathrm{c}$ & 29.79 & $421.07 \mathrm{a}$ & $138 b$ \\
\hline 20 & FLIP2009-13L & $26.70 \mathrm{~d}$ & $0.64 d$ & $3.17 \mathrm{~d}$ & 25.84 & $217.98 b$ & $147 \mathrm{a}$ \\
\hline 21 & FLIP2009-14L & $55.01 \mathrm{c}$ & $1.37 \mathrm{c}$ & $4.43 c$ & 28.89 & $363.83 a$ & $143 a$ \\
\hline 22 & FLIP2009-15L & $30.72 d$ & $0.73 \mathrm{~d}$ & $3.32 \mathrm{~d}$ & 20.59 & $207.85 b$ & $148 \mathrm{a}$ \\
\hline 23 & FLIP2009-16L & $44.60 \mathrm{c}$ & $1.11 \mathrm{c}$ & $3.99 \mathrm{c}$ & 27.13 & $100.50 \mathrm{~b}$ & $144 a$ \\
\hline 24 & FLIP2009-17L & $41.59 c$ & $1.15 \mathrm{c}$ & $4.23 c$ & 31.20 & $175.88 b$ & $148 \mathrm{a}$ \\
\hline 25 & FLIP2009-18L & $23.40 \mathrm{~d}$ & $0.67 \mathrm{~d}$ & $4.17 \mathrm{c}$ & 29.47 & $104.13 b$ & $140 \mathrm{~b}$ \\
\hline 26 & FLIP2009-19L & $129.83 a$ & $3.42 \mathrm{a}$ & $4.20 \mathrm{c}$ & 24.84 & $469.34 \mathrm{a}$ & $148 \mathrm{a}$ \\
\hline 27 & FLIP2009-25L & $59.06 \mathrm{c}$ & $1.49 \mathrm{c}$ & $4.42 \mathrm{c}$ & 28.57 & $102.03 b$ & $138 b$ \\
\hline 28 & FLIP2009-26L & $48.59 c$ & $1.27 \mathrm{c}$ & $4.42 \mathrm{c}$ & 28.44 & $272.35 b$ & $145 \mathrm{a}$ \\
\hline 29 & FLIP2009-27L & $51.69 \mathrm{c}$ & $1.61 \mathrm{c}$ & $4.30 \mathrm{c}$ & 29.25 & $378.55 \mathrm{a}$ & $144 a$ \\
\hline 30 & FLIP2010-2L & $33.10 \mathrm{c}$ & $1.45 \mathrm{c}$ & $5.47 \mathrm{a}$ & 49.70 & $239.93 b$ & $149 a$ \\
\hline 31 & FLIP2010-8L & $15.09 \mathrm{~d}$ & $0.55 \mathrm{~d}$ & $5.19 b$ & 48.55 & $225.65 b$ & $148 \mathrm{a}$ \\
\hline 32 & FLIP2010-12L & $21.96 \mathrm{~d}$ & $0.61 d$ & $4.72 b$ & 43.45 & $141.59 b$ & $144 \mathrm{a}$ \\
\hline 33 & FLIP2010-19L & $33.10 \mathrm{c}$ & $1.45 \mathrm{c}$ & $5.47 \mathrm{a}$ & 35.93 & $188.41 \mathrm{~b}$ & $149 a$ \\
\hline 34 & FLIP2010-20L & $15.09 \mathrm{~d}$ & $0.55 \mathrm{~d}$ & $5.19 b$ & 38.06 & $714.00 \mathrm{a}$ & $148 \mathrm{a}$ \\
\hline 35 & FLIP2010-21L & $21.96 \mathrm{~d}$ & $0.61 \mathrm{~d}$ & $4.72 b$ & 30.50 & $166.19 b$ & $144 a$ \\
\hline 36 & FLIP2010-22L & $25.91 d$ & $0.62 \mathrm{~d}$ & $3.83 \mathrm{~d}$ & 24.40 & $68.63 b$ & $148 \mathrm{a}$ \\
\hline 37 & FLIP2010-23L & $38.54 \mathrm{c}$ & $0.61 d$ & $5.07 \mathrm{~b}$ & 29.05 & $150.95 b$ & $146 \mathrm{a}$ \\
\hline 38 & FLIP2010-24L & $40.34 c$ & $1.18 \mathrm{c}$ & $4.26 \mathrm{c}$ & 28.78 & $242.75 b$ & $141 b$ \\
\hline 39 & FLIP2010-27L & $152.29 \mathrm{a}$ & $4.49 \mathrm{a}$ & $4.54 \mathrm{c}$ & 28.30 & $426.82 \mathrm{a}$ & $140 \mathrm{~b}$ \\
\hline 40 & FLIP2010-28L & $14.12 d$ & $0.31 \mathrm{~d}$ & $3.14 \mathrm{~d}$ & 32.09 & $56.54 b$ & $140 \mathrm{~b}$ \\
\hline 41 & FLIP2010-29L & $40.41 \mathrm{c}$ & $0.91 d$ & $3.90 \mathrm{~d}$ & 27.00 & $122.49 b$ & $141 b$ \\
\hline 42 & FLIP2010-30L & $53.21 \mathrm{c}$ & $1.82 \mathrm{c}$ & $4.31 \mathrm{c}$ & 27.98 & $121.37 \mathrm{~b}$ & $146 a$ \\
\hline 43 & FLIP2010-31L & $77.68 \mathrm{~b}$ & $2.11 b$ & $4.22 \mathrm{c}$ & 29.15 & $323.05 a$ & $146 a$ \\
\hline 44 & FLIP2010-32L & $50.75 c$ & $1.68 \mathrm{c}$ & $3.95 \mathrm{c}$ & 24.03 & $230.07 b$ & $144 a$ \\
\hline 45 & FLIP2010-99L & $85.34 b$ & $2.62 b$ & $4.52 \mathrm{c}$ & 31.78 & $976.91 \mathrm{a}$ & $138 b$ \\
\hline 46 & FLIP2010-100L & $149.37 \mathrm{a}$ & $4.34 \mathrm{a}$ & $4.10 \mathrm{c}$ & 28.49 & $325.23 \mathrm{a}$ & $138 b$ \\
\hline 47 & FLIP2010-106L & $134.68 \mathrm{a}$ & $4.15 \mathrm{a}$ & $4.24 \mathrm{c}$ & 30.37 & $682.67 \mathrm{a}$ & $143 \mathrm{a}$ \\
\hline 48 & SILVINA & $71.42 \mathrm{~b}$ & $3.74 \mathrm{a}$ & $5.73 a$ & 53.47 & $2259.03 a$ & $127 \mathrm{c}$ \\
\hline 49 & 6031 & $47.50 \mathrm{c}$ & $1.39 \mathrm{c}$ & $3.86 \mathrm{~d}$ & 26.68 & $217.29 b$ & $133 c$ \\
\hline
\end{tabular}

*averages followed by the same lowercase letter in the column and uppercase letter in the line belong to the same group by the Scott and Knott test $(\mathrm{p}<5 \%)$. 
Table 4. Grouping through Tocher's method based on the calculated distance by Jaccard's method among 49 lentil genotypes, 48 experimental inbred lines and the commercial cultivar Sílvina. Brasília, Embrapa Hortaliças, 2020.

\begin{tabular}{|c|c|}
\hline $\begin{array}{l}\text { Group } \\
\text { (number) }\end{array}$ & Genotypes \\
\hline 1 & $\begin{array}{l}\text { FLIP 2007-74L; FLIP 2009-17L; FLIP 2007-42L; FLIP 2010-32L; FLIP 2009-26L; FLIP 2010-30L; FLIP } \\
\text { 2010-24L; FLIP 2010-22L; FLIP 2009-25L; FLIP 2010-29L; FLIP 2007-77L; FLIP 2009-18L; FLIP 2009- } \\
\text { 7L; FLIP 90-25L; FLIP 2009-14L; FLIP 2009-15L; FLIP 2009-13L; FLIP 2009-16L; FLIP 2009-2L; FLIP } \\
\text { 2009-27L; 81S15; FLIP 2010-23L; FLIP 2010-20L; FLIP 2009-4L; FLIP 2009-9L; FLIP 2009-5L; FLIP } \\
\text { 2010-28L; FLIP 2010-99L; FLIP 2009-10L; FLIP 2009-11L; FLIP 2009-1L; FLIP 2007-75L; FLIP 2010- } \\
\text { 31L; FLIP 2009-12L; FLIP 2008-2L }\end{array}$ \\
\hline 2 & FLIP 2010-21L \\
\hline 3 & FLIP 2009-19L \\
\hline 4 & FLIP 2010-27L; FLIP 2010-100L; FLIP 2010-106L; 6031 \\
\hline 5 & $\begin{array}{l}\text { FLIP 2010-2L; FLIP 2010-8L; FLIP 2010-19L; FLIP 2007-11L; FLIP 2007-16L; FLIP 2010-12L; FLIP } \\
\qquad 2007-28 \mathrm{~L}\end{array}$ \\
\hline 6 & Silvina \\
\hline
\end{tabular}

Of the 35 genotypes grouped in the first group by the Tocher's test, 34 were covered by groups I and II of the dendrogram. Groups II, III and IV of the Tocher's test were fully contemplated by group II from the dendrogram, except genotype 6031, included in group III from the dendrogram. Genotypes, macrosperm type (FLIP 2010-8L, FLIP 2007-16L, FLIP 2007-11L, FLIP 2010$2 \mathrm{~L}$ and Silvina), were distributed among groups I, IV and V of the dendrogram; however, they were all gathered in group V by Tocher's test, except Silvina, who formed an isolated group in this last test.

Grouping data themselves do not allow to define crosses, as the genetically distinct inbred lines do not necessarily have the best combining ability (Vaz et al., 2017). We should also take into consideration the best averages for traits of interest among the contrasting inbred lines, allowing more frequent combination among superior genotypes (Cruz et al., 2012). Thus, taking into consideration traits such as growing habit, seed coating color, cotyledon color, plant height, number of days until flowering beginning, weight of 1000 seeds and productivity, inbred lines FLIP2010-8L and FLIP2010-12L (group I), FLIP2010-99L, FLIP201020L and FLIP2010-106L (group II), FLIP90-25L and 6031 (group III), FLIP2007-16L (group IV) and commercial cultivar Silvina (group V) showed to be more promising to be used in breeding programs of the species.

Genotypes FLIP2010-99L, FLIP2010-20L, FLIP2010-106L and FLIP90-25L showed the best averages for traits of commercial interest within microsperm group. In macrosperm group, cultivar Silvina showed outstandingly high productivity values. As a matter of fact, in this study, no genotype, macrosperm type, was identified as superior to the already existing commercial cultivar. Using the association of grouping techniques with characterization data, we could identify divergent and, at the same time, superior genotypes regarding agronomic traits: FLIP2010-8L and FLIP2010-12L (group I), FLIP2010-99L, FLIP201020L and FLIP2010-106L (group II), FLIP90-25L and 6031 (group III), FLIP2007-16L (group IV) and the commercial cultivar Silvina (group V). These genotypes showed potential for being used in breeding programs of the species.

\section{REFERENCES}

BURLE, ML; OLIVEIRA, MSP. 2010. Manual de curadores de germoplasma vegetal: caracterização morfológica. Brasília: Embrapa Recursos Genéticos e Biotecnologia, Belém: Embrapa Amazônia Oriental. 15p. (Documentos, 312, 378).

COMEX STAT. 2021. Exportação e importação geral. Available http://comexstat.mdic.gov.br/ pt/geral. Accessed January 20, 2021.

CRUZ, CD. 2013. Genes - a software package for analysis in experimental statistics and quantitative genetics. Acta Scientiarum. Agronomy 35: 271-276.

CRUZ, CD; REGAZZI, AJ; CARNEIRO, PCS. 2012. Modelo biométrico aplicado ao melhoramento genético. Viçosa: UFV.

DIEKMANN, J; AL-SALEH, Y. 2009. Mechanization. In: ERSKINE W; MUEHLBAUER FJ; SARKER A; SHARMA $\mathrm{B}$ (eds). The lentil: Botany, production and uses. Wallingford, UK: CABI International. p.121-136.

EMBRAPA HORTALIÇAS. 2014. Cultivares da Embrapa Hortaliças (1981-2013). Brasília, DF: Embrapa. p.80-81.

FAOSTAT. 2020. Crop, lentil production in the world. Available http://www.fao.org/faostat/ en/\#data/QC/visualize. Accessed January 20, 2020.

FERREIRA, CA; PINHO, EVRV; PAIVA, PDO; PEREIRA, GS; DINIZ, RP. 2011. Identificação de cultivares e certificação da pureza genética de gladíolo por meio de marcadores morfológicos. Ciência e Agrotecnologia 35: 692-700.

GIORDANO, LB; PEREIRA, W; LOPES, JF. 1988. Cultivo da lentilha. Brasília: Embrapa Hortaliças. 3p. (Instruções Técnicas, 9).

GIORDANO, LB; NASCIMENTO, WM. 2009. Lentilha Silvina - precocidade e sabor. Brasília: Embrapa Hortaliças (folder).

INMET. 2018. Estações convencionais gráfico. Available http://www.inmet.gov.br/ portal/index.php?r=home/page\&page=rede estacoes_conv_graf. Accessed December 1,2018 .

KUMAR, J; SRIVASTVA, E; SINGH, M. 2013. Genetics of early growth vigour in lentil (Lens culinaris Medik.). Journal of Genetics 92: 323 . 
KOTTEK, M; GRIESER, J; BECK, C; RUDOLPH, B; RUBEL, F. 2006. World map of the Köppen Geiger climate classification updated. Meteorologische Zeitschrift 15: 259- 263.

LIU, K; BLACKSHAW, E; JOHNSON, EN; HOSSAIN, Z; HAMEL, C; ST-ARNAUD, M; GAN, Y. 2019. Lentil enhances the productivity and stability of oil seed-cereal cropping systems across different environments. European Journal of Agronomy 105: 24-31.

MALHOTRA, N; PANATU, S; SINGH, B; NEGI, N; SINGH, D; SINGH, M; CHANDORA, R. 2019. Genetic resources: collection, conservation, characterization and maintenance. In: SINGH, M (ed). Lentils: potential resources for enhancing genetic gains. The Netherlands: Elsevier. p.21-41.

MAROUELLI, WA; CALBO, AG. 2009. Manejo de irrigação em hortaliças com Sistema Irrigas. Brasília: Embrapa Hortaliças, 16p. (Circular técnica 69).

PIMENTEL-GOMES, F. 2009. Curso de estatística experimental. Piracicaba: BR: ESALQ. 451p.

RAWAL, V; BANSAL, V. 2019. Lentil: emergence of large-scale, export-oriented production. In: RAWAL, V; NAVARRO, DK (eds). The global economy of pulses. Rome: FAO. p.71-85.
RASHEED, M; NASEER, T; HASSAN, A; HASSAN F; HAYAT, R; JILANI, G; VASEER, SG; ALI, MB. 2020. Isolation of nodule associated bacteria for promotion of lentil growth. Pakistan Journal of Agricultural Research 33: 170-179.

ROY, S; ISLAM, MA; SARKER, A; ISMAIL, MR; RAFIL, MY; MONDAL, MMA; MALEK, MA. 2012. Morphological characterization of lentil accessions: qualitative characters. Bangladesh Journal of Botany 2: 187-190.

SAS Institute (Cary, NC). 2009. SAS System for Windows. Version 9.2: software.

SAXENA, MC. 2009. Plant morphology, anatomy and growth habit. In: ERSKINE, W; MUEHLBAUER, FJ; SARKER, A; SHARMA, B (eds). The lentil botany, production and uses. Wallingford, UK: CABI International. p.34-46.

SHAHWAR, D; BHAT, TM; ANSARI, MYK; CHAUDHARY, S; ASLAM, R. 2017. Health functional compounds of lentil (Lens culinaris Medik): A review. International Journal of Food Properties, 201: 1-15.

SHARMA, B. 2009. Genetics of economic traits. In: ERSKINE, W; MUEHLBAUER, FJ; SARKER, A; SHARMA, B (eds). The lentil botany, production and uses. Wallingford, $\mathrm{UK}$ : CABI International. p.78-101.
STRYDHORST, S; OLSON, MA; VASANTHAN, T; McPHEE, KE; McKENZIE, RH; HENRIQUEZ, B; TIEULIE, J; MIDDLETON, A; DUNN, R; PFIFFNER, P; COLES, MB; KRUGER, A; BOWNESS, R; BING, DJ; BEAUCHESNE, D. 2015. Adaptability and quality of winter pea and lentil in Alberta. Agronomy Journal 107: 2431-2448.

UPOV. 2015. Lentil. UPOV code: LENSS CUL. Lens culinaris Medik. Guidelines for the conduct of the tests of distinctness, homogeneity and stability, TG/210/2. UPOV, International Union for the Protection of New Varieties of plants, Geneva, Swittzerland. Available www.upov.int/edocs/tgdocs/en/ tg210.pdf. Accessed March 5, 2017.

VAZ, DC; MORAIS JÚNIOR, OP; PEIXOTO, N. 2017. Agro-morphological characterization and genetic divergence assessment in bush snap bean genotypes. Pesquisa Agropecuária Tropical 47: 134-144.

VIEIRA, RF. 2003. Potencialidade da cultura da lentilha em Coimbra, Minas Gerais. Ceres. 50(291).

VIEIRA, RF; LIMA, RC. 2016. Lentilha. In: NASCIMENTO, WM (ed). Hortaliças Leguminosas. 1 ed. p.121-146.

VIEIRA, RF; VIEIRA, C; VIEIRA, RF. 2001. Leguminosas graniferas. Viçosa: Editora UFV. p.161-168. 